\title{
Prevalence of Human Papillomavirus by DNA Chip Test in Women
}

\author{
Jae-Woo Kim, Yun-Tae Kim', Dae-Sik Kim² and Seok-Cheol Choi* \\ Department of Clinical Laboratory Science, College of Health Sciences, Catholic University of Pusan, Busan 609-757, Korea \\ ${ }^{1}$ Seoul Medical Science Institute (SMSI), Seoul 140-809, Korea \\ ${ }^{2}$ Department of Clinical Laboratory Science, Dongnam Health College, Suwon 440-714, Korea
}

Received November 5, 2008 /Accepted December 24, 2008

\begin{abstract}
We determined the prevalence of human papillomavirus (HPV) by DNA chip test in 549 women and cytologic diagnosis. 237 of 549 women (43.17\%) subjected with HPV DNA Chip examination were found positive for HPV. 210 (88.60\%, High group) were infected with high-risk HPV types. 17 (7.17\%, Low group) were infected with low-risk HPV types $(6,11,40,44,70)$ and 17 (7.17\%, Mixed group) were infected with mixed types. According to age, in their twenties, thirties, forties, fifties and over sixties, the prevalence of infection with high-risk HPV types were $1.26 \%(3 / 237), 15.61 \%(37 / 237)$, $31.65 \%$ (75/237), 23.21\% (55/237), and 13.92\% (33/237), respectively. In the Low and Mixed group, percentages of infection with HPV were significantly lower than that of the High group. On the comparison of cytologic diagnosis (224 women) by Pap smear and DNA chip positive (237 women) for HPV, 132 out of 194 cases in the High group (68.04\%) suffered cervical lesions with ASCUS (atypical squamous cells of undetermined significance, 7.22\%), LSIL (low grade squamous intraepithelial lesion, $15.98 \%$ ), HSIL (high grade SIL, 23.20\%) and ICC (invasive cervical cancer, 21.65\%). The Low group (14/224 women) showed 1 case of ASCUS and 6 cases of LSIL, whereas the Mixed group (4/224 women) had only 2 cases of ASCUS. According to the HPV subtypes, the high-risk types 16 and 18 induced 26 and 7 cases of ICC, respectively, whereas other HPV subtypes induced lower or no ICC incidence. In conclusion, the present data imply that the prevalence of HPV was $43.17 \%$, high-risk HPV type 16 is a major factor, which causes precancerous and/or cervical cancer in woman and that HPV DNA chip is an accurate and useful tool for detecting HPV.
\end{abstract}

Key words : Human paillomavirus, cervical cancer, DNA chip, Pap smear

\section{Introduction}

The development of the Pap smear by Papanicolaou has contributed to reduce morbidity and mortality in patients with cervical cancer. It is unquestionable that the Pap smear is the best example of a successful cervical cancer screening $[12,13]$. However, the Pap smear test has a limitation with false negative although it is an excellent screening test. Sherman et al. [15] showed that ASCUS (atypical squamous cells of undetermined significance) cytology reports are not reproducible, even by expert cytopathologists. Several studies demonstrated that even though the majority of ASCUS findings by Pap smear represents a benign reactive process, 5 to $10 \%$ of the women with ASCUS have potential for HSIL (high grade squamous intraepithelial lesion) $[4,9,17]$. Human papillomavirus, which is sexually transmitted, is a strong agent of cervical cancer [18]. HPV can infect basal epithelial

\section{*Corresponding author}

Tel : +82-51-510-0564, 0569, Fax : +82-51-510-0568

E-mail : scchoi@cup.ac.kr cells of the skin or inner lining of tissues and are classified as cutaneous type and mucosal type. Cutaneous types are epidermitrophic and target the skin of the hands and feet, while mucosal types infect the lining of the mouth, throat, respiratory tract, or genital epithelium. Methods for detecting HPV include PCR, in situ hybridization, Hybrid-Capture II assay, and HPV DNA chip test. Although HAP DNA chip test has merits such as identification for 22 to 24 genotypes of HPV, it has been less used compared with HybridCapture II assay. However, we do not have enough data for studies of HPV DNA chip in Korea.

This study was carried out to investigate the prevalence of human papillomavirus (HPV) by DNA chip test in 549 women and cytologic diagnosis.

\section{Materials and Methods}

\section{Patients}

In 2006, 549 women were tested for human papillomavirus (HPV) by DNA chip. 237 women having tested positive on the HPV DNA chip test were subjected to this 
study. A cytologic test was carried out for 224 out of 237 women. Finally, the data of 224 patients were analyzed in the present study. Cytologic diagnosis was determined by Pap smear.

\section{Cytologic diagnosis}

Specimens were collected by scraping the endocervix and ectocervix with a brush.

The specimens were smeared on a slide glass and immediately immersed in 95\% alcohol for test. The Pap stain procedure was the following : the specimen on the slide glass was fixed in 95\% alcohol for $30 \mathrm{~min}$ and washed in tap water. The Nucleus in the specimen was stained with Harris' hematoxylin (Sigma, America), decolorized with 1\% HCL-alcohol and neutralized in tap water for $10 \mathrm{~min}$. The Cytoplasm was stained with orange G (Young Dong Diagnostics., Korea) for 2 min and with EA 50 (Young dong Co., Korea) for $2 \mathrm{~min}$. The specimen was hydrated in absolute alcohol and mounted with Synthetic Mountant (Shandon, England).

Pathologists interpreted the results of the specimen and classified them with TBS (the Bethesda system).

\section{HPV DNA chip test}

A specimen was taken by cytobrush of HPV DNA chip sampler (BioMed Lab., Korea) from the endocervix and ectocervix and inserted into a transfer medium. The HPV DNA chip test was performed as follows.

\section{DNA isolation}

The specimen was isolated from cytobrush by strong vortexing and inserted into a microcentrifuge tube of $1.5 \mathrm{ml}$. It was centrifuged with $8,800 \mathrm{rpm}$ for $10 \mathrm{~min}$ and the supernatant was removed. The pellet with $1 \mathrm{ml}$ of $1 \times$ washing buffer (10× washing buffer + DW) was mixed in vortex, centrifuged with 8,800 rpm for $5 \mathrm{~min}$ and the supernatant was removed. $200 \mu \mathrm{l}$ of DNA extraction buffer was mixed, incubated into water bath of $50^{\circ} \mathrm{C}$ for over $3 \mathrm{hrs}$ and boiled at $90-100^{\circ} \mathrm{C}$ for $20 \mathrm{~min}$. It was centrifuged with $14,000 \mathrm{rpm}$ for $10 \mathrm{~min}$ and 100-150 $\mu \mathrm{l}$ of supernatant was prepared for PCR analysis.

\section{Polymerase chain reaction (PCR) analysis}

PCR procedures consisted of three steps. The first step of PCR was as follows; $6.5 \mu \mathrm{l}$ of PCR I, $0.3 \mu \mathrm{l}$ of Taq polymerase and $12.7 \mu \mathrm{l}$ of DW were infused into PCR tube and 5 $\mu \mathrm{l}$ of DNA extractive was added into it. This mixed DNA was amplified as follows; initial denaturation at $50^{\circ} \mathrm{C}$ for 3 min followed by 1 cycle of $95^{\circ} \mathrm{C}$ for $15 \mathrm{~min}$. And, procedures such as $95^{\circ} \mathrm{C}$ for $30 \mathrm{sec}, 55^{\circ} \mathrm{C}$ for $30 \mathrm{sec}, 35$ cycles of $72^{\circ} \mathrm{C}$ for $30 \mathrm{sec}$, and a final cycle of $72^{\circ} \mathrm{C}$ for 3 min were employed. The second PCR procedures were the following; $6.5 \mu \mathrm{l}$ of PCR II, $0.3 \mu \mathrm{l}$ of Taq polymerase and $16.2 \mu \mathrm{l}$ of DW were infused into PCR tube and $2 \mu \mathrm{l}$ of the first PCR product was added into it. One cycle of $95^{\circ} \mathrm{C}$ for $5 \mathrm{~min}$ and procedures such as $95^{\circ} \mathrm{C}$ for $30 \mathrm{sec}, 55^{\circ} \mathrm{C}$ for $40 \mathrm{sec}, 20$ cycles of $72^{\circ} \mathrm{C}$ for $30 \mathrm{sec}$, and a final cycle of $72^{\circ} \mathrm{C}$ for $3 \mathrm{~min}$ were performed.

\section{Hybridization}

$10 \mu \mathrm{l}$ of the 2 nd product was denaturated at $95^{\circ} \mathrm{C}$ for 5 min. Frozen hybridization buffer was incubated at $43^{\circ} \mathrm{C} 10$ min until it was utilized. Denatured $10 \mu \mathrm{l}$ of the 2 nd product combined with $30 \mu \mathrm{l}$ of hybridization buffer were distributed into a well of HPV DNA Chip slide under appropriate humidity. After hybridization at $43^{\circ} \mathrm{C}$ for 2 to $3 \mathrm{hr}$, the hybridization seal was removed from the slide. It was respectively washed two times with washing buffer I [2× SSC (sodium citrate, sodium chloride), 0.1\% SDS (sodium dodecyl sulfate)] for $5 \mathrm{~min}$, two times with buffer II [0.2× SSC] for $5 \mathrm{~min}$, and one time with buffer III [0.1 $\times$ SSC]. The HPV DNA chip includes 24 type specific probes; 16 types are high-risk group (HPV-16, HPV-18, HPV-31, HPV-33, HPV-35, HPV-39, HPV-45, HPV-51, HPV-52, HPV-53, HPV-54, HPV-56, HPV-58, HPV-59, HPV-66, HPV-68) and 8 types are low-risk group (HPV-6, HPV-11, HPV-34, HPV-40, HPV-42, HPV-43, HPV-44, HPV-70). Positive and negative control were utilized in every test.

\section{Interpretation}

The HPV type was determined by scanning (ScanArray Gx, PerkinElmer, America) after air drying at room temperature.

\section{Results and Discussion}

\section{Cytologic diagnosis}

Table 1 shows the cytologic diagnosis according to age in $224 \mathrm{HPV}$ positive women. 70 women (35.27\%, Fig. 1) were normal, ASCUS was detected in 19 out of 224 women $(8.48 \%)$ consisting of 1 case in the age group 20 years (5.26\%), 4 cases in the age group 30 years $(21.05 \%), 7$ cases in the age group 40 years $(36.84 \%), 5$ cases in the age group 50 
Table 1. Finding of cytologic diagnosis according to age group

\begin{tabular}{lccrrrc}
\hline \multirow{2}{*}{$\begin{array}{c}\text { Cytologic diagnosis } \\
\text { (case, \%) }\end{array}$} & $20-29(\mathrm{n}=4)$ & $30-39(\mathrm{n}=40)$ & $40-49(\mathrm{n}=84)$ & $50-59(\mathrm{n}=60)$ & $>60(\mathrm{n}=36)$ & Total $(\mathrm{n}=224)$ \\
\cline { 2 - 7 } & $1(1.26 \%)$ & $12(15.19 \%)$ & $33(41.77 \%)$ & $22(27.85 \%)$ & $11(13.92 \%)$ & $79(35.27 \%)$ \\
Normal (79) & $1(5.26 \%)$ & $4(21.05 \%)$ & $7(36.84 \%)$ & $5(12.82 \%)$ & $2(10.53 \%)$ & $19(8.48 \%)$ \\
ASCUS (19) & 0 & $4(10.26 \%)$ & $19(48.72 \%)$ & $9(23.08 \%)$ & $7(17.95 \%)$ & $39(17.41 \%)$ \\
LSIL (39) & $2(4.44 \%)$ & $15(33.33 \%)$ & $14(31.11 \%)$ & $9(20.00 \%)$ & $5(11.11 \%)$ & $45(20.09 \%)$ \\
HSIL (45) & 0 & $5(11.90 \%)$ & $11(26.19 \%)$ & $15(35.71 \%)$ & $11(26.19 \%)$ & $42(18.75 \%)$ \\
Invasive Ca (42) & 0 &
\end{tabular}

Abbreviations: ASCUS, atypical squamous cells of undetermined significance; LSIL, low grade squamous intraepithelial lesion; HSIL, high grade squamous intraepithelial lesion; Ca, cervical carcinoma.

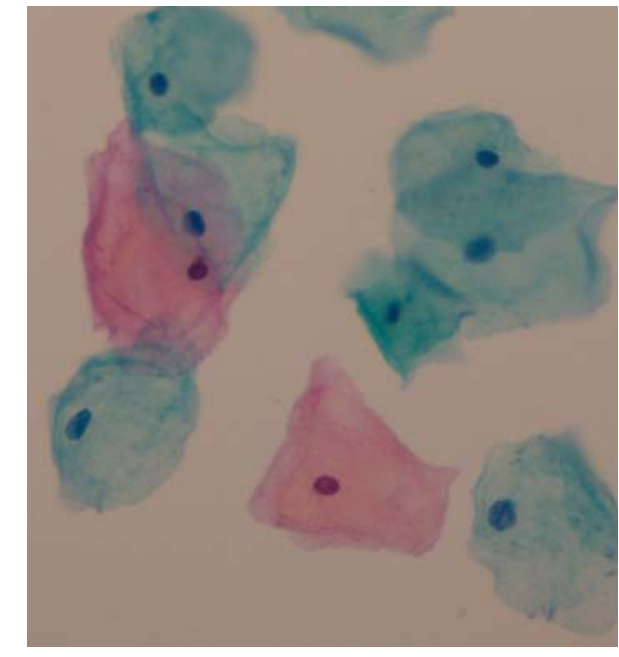

Fig. 1. Normal superficial (eosinophilic) and intermediate (basophilic) cells by cytologic finding with Pap stain. Abundant cytoplasm has a polygonal form. It is thin and transparent. Eosinophilic cytoplasm may possess thin and/or folded cytoplasm. The round nucleus of superficial cell is smaller than a red blood cell (RBC) and karyopyknotic. The nucleus of an intermediate cell, which is larger than a RBC, is round to oval and vesicular with finely divided, evenly distributed chromatin.

years $(26.32 \%)$, and 2 cases in the age group 60 years and older (10.53\%) (Fig. 2). LSIL was detected in 39 out of 224 women $(17.41 \%)$ consisting of 4 cases in the age group 30 years $(10.26 \%), 19$ cases in the age group 40 years $(48.72 \%)$, 9 cases in the age group 50 years (23.08\%), and 7 cases in the age group 60 years and older (17.95\%) (Fig. 3). HSIL was found in 45 out of 224 women (20.09\%) with 2 cases in the age group 20 years (4.44\%), 15 cases in the age group 30 years $(33.33 \%), 14$ cases in the age group 40 years $(31.11 \%), 9$ cases in the age group 50 years $(20.00 \%)$, and 5 cases in the age group 60 years and older (11.11\%) (Fig. 4). Invasive cervical carcinoma (ICC) was detected in 42 out of 224 women $(17.72 \%)$ with 5 cases in the age group 30

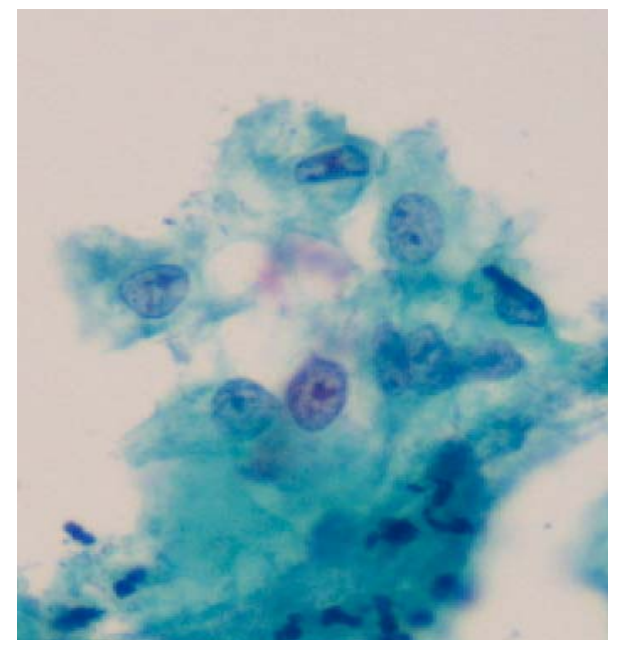

Fig. 2. Finding of ASCUS (Atypical squamous cells of undetermined significance). The nuclei are 2 to 3 times the size of that of intermediate cells. These cells have slightly increased nuclear/cytoplasmic ratio. It shows a smooth membrane or very limited irregularity with mild hyperchromatin and evenly distributed chromatin without granularity. The cytoplasm is usually mature superficial/intermediate type.

years $(11.90 \%), 11$ cases in the age group 40 years $(26.19 \%)$, 15 cases in the age group $50(35.71 \%)$, and 11 cases in the age group 60 years and older (26.19\%) (Fig. 5). Overall, the prevalence of ASCUS and LSIL was highest in the age group 40 years, and that of HSIL was highest in age group 30 years with vigorous sexual activity. The patients in the age group 50 years suffered invasive cervical carcinoma because they may have a menopausal disorder or they may be going through menopause.

Our findings were different from previous studies. Hong et al. [5] reported lower prevalence of abnormal findings than our results. They investigated subjects with and without HPV infection. However, Hwang [6] showed similar results in his study on women with HPV infection. 


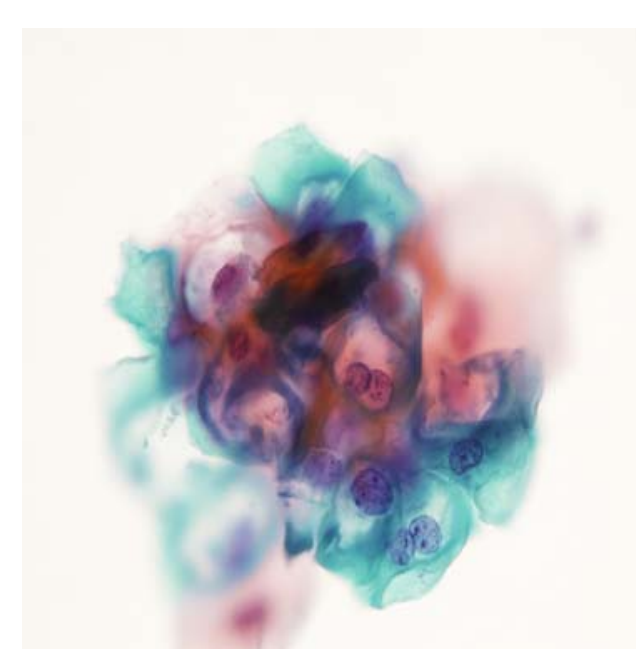

Fig. 3. Finding of LSIL (low-grade squamous intraepithelial lesion). The nuclei are at least 3 times the size of that of intermediate cells. They have increased nuclear/cytoplasmic ratio, binucleation or multinucleation. Nuclear membranes are slightly irregular, and show hyperchromasia with uniform chromatin distribution, chromatin degeneration and smudging. The cytoplasm has irregular perinuclear clearing (halo).

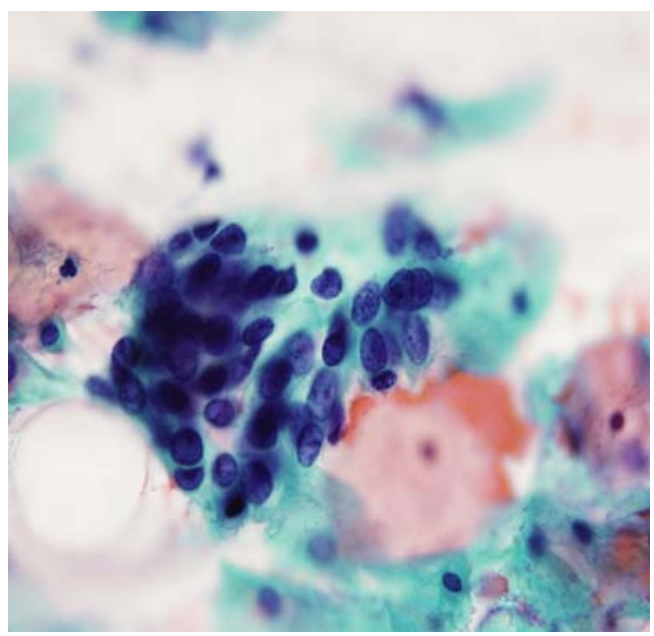

Fig. 4. Finding of HSIL(high-grade squamous intraepithelial lesion). nucleoli are enlarged in range of LSIL but diminished amount of cytoplasm and marked increase in nuclear/cytoplasmic ratio. Nuclear membranes are irregular. They have hyperchromasia, fine to coarse, and evenly distributed chromatin. Nucleoli are generally absent and the cytoplasm is lacy and delicate.

\section{HPV DNA test}

If patients were infected with HPV, a fluorescent color can be seen (Fig. 6). 237 of 549 women (43.17\%) subjected to the HPV DNA Chip examination were found positive for HPV.

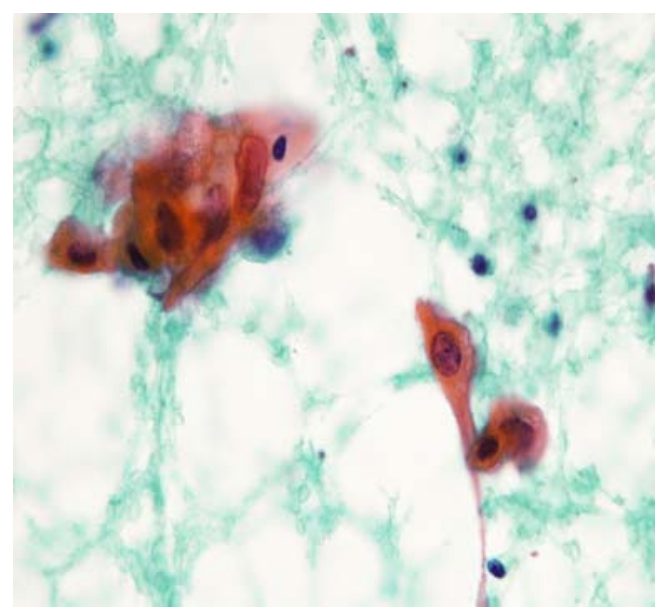

Fig. 5. Finding of invasive cervical carcinoma. Nuclei show a marked variation of size/shape, numerous dense, opaque forms chromatin, which is coarsely granular and irregularly distributed. Parachromatin is clear and macronucleoli are present. The cytoplasm is frequently dense and orangeophilic.
(A) (10) (10) (11) (51) (51) (68) (66)
(44) (44) (14) (45) (45) (66) (66)
(43) (43) (14) (39) (39) (59) (59)
(42) (42) (14) (35) (35) (59) (56)
(40) (40) (14) (33) (33) (56) (56)
(34) (34) (14) (31) (31) (54) (54)
(11) (11) (ii) (18) (11) (53) (5:)
(6) (6) (14) (16) (16) (52) (5)

(B)

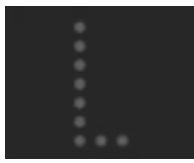

Type 16

(C)

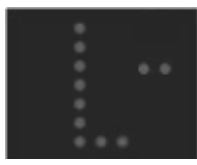

Type 16,58

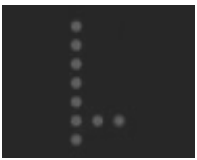

Type 18

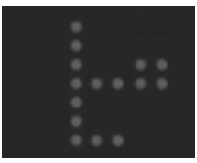

Type 33,58

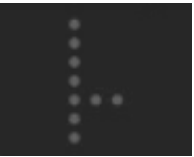

Type 31

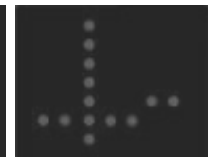

Type $11,18,54$ Type $16,33,56,58$
Fig. 6. (A) Interpretation of HPV DNA chip test. M-markers are control. Left circles are low-risk HPV subtypes. Right circles indicate high-risk HPV subtypes. (B) Single infection cases of HPV subtypes. (C) Multiple infection cases of HPV subtypes.

Incidences of HPV infection were summarized in Table 2. Among 237 cases, 203 cases (85.65\%) were high-risk HPV infections and were comprised of single infections (with one subtype), infections with two, three, and four subtypes. In 
single and two-types infections, patients in their forties had the highest incidence, in three- and four-type infections patients in their thirties had the highest prevalence. These data suggest that age group 30 and 40 years with energetic sexual activity may be exposed to more risk of HPV infection. On the other hand, 17 cases (7.17\%) were identified as low-risk HPV infections. The highest incidence was in patients in their forties. Mixed types (with single infections high-risk and low-risk HPV or multiple infections high-risk and low-risk HPV) and unidentified type infections were re- spectively found in $12(5.06 \%)$ and $5(2.10 \%)$ cases. In all cases, age group 40 years had the highest prevalence of HPV infections. These results were similar to previous studies. Muñoz et al. [11] demonstrated the highest prevalence of both groups in women in their 40s with and without squamous-cell cervical cancer. Hong et al. [5] explained that patients aged between 35 to 54 years were highly infected with HPV. Furthermore, Kim et al. [8] found that women in the 40 years age group had the highest HPV detection and HSIL. However, Lazacano-Ponce et al., [10] whom investigated on

Table 2. Incidences of HPV infection by DNA chip according to age group

\begin{tabular}{|c|c|c|c|c|c|c|}
\hline \multirow{2}{*}{ HPV type } & \multicolumn{6}{|c|}{ Age (year) } \\
\hline & $20-29(n=4)$ & $30-39(n=44)$ & $40-49(n=88)$ & $50-59(n=64)$ & $>60 \quad(n=37)$ & Total (237case) \\
\hline \multicolumn{7}{|l|}{ High-risk HPV (case, \%) } \\
\hline Single infection & $2(0.84 \%)$ & $25(10.54 \%)$ & $62(26.16 \%)$ & $50(21.10 \%)$ & $29(12.23 \%)$ & $168(70.88 \%)$ \\
\hline \multicolumn{7}{|l|}{ Multiple infection } \\
\hline 2 types & $1(0.42 \%)$ & $9(3.79 \%)$ & $12(5.06 \%)$ & $4(1.69 \%)$ & $3(1.26 \%)$ & $29(12.23 \%)$ \\
\hline 3 types & 0 & $2(0.84 \%)$ & $1(0.42 \%)$ & $1(0.42 \%)$ & $1(0.42 \%)$ & $5(2.10 \%)$ \\
\hline 4 types & 0 & $1(0.42 \%)$ & 0 & 0 & 0 & $1(0.42 \%)$ \\
\hline Total & $3(1.26 \%)$ & $37(15.60 \%)$ & $75(31.64 \%)$ & $55(23.20 \%)$ & $33(13.92 \%)$ & $210(88.61 \%)$ \\
\hline \multicolumn{7}{|l|}{ Low risk HPV (case, \%) } \\
\hline Single infection & 0 & $4(1.69 \%)$ & $6(2.53 \%)$ & $5(2.10 \%)$ & $1(0.42 \%)$ & $16(6.75 \%)$ \\
\hline \multicolumn{7}{|l|}{ Multiple infection } \\
\hline 2 types & 0 & 0 & $1(0.42 \%)$ & 0 & 0 & $1(0.42 \%)$ \\
\hline Total & 0 & $4(1.69 \%)$ & $7(2.95 \%)$ & $5(2.10 \%)$ & $1(0.42 \%)$ & $17(7.17 \%)$ \\
\hline \multicolumn{7}{|l|}{ Mixed types (case, \%) } \\
\hline High single +low & 0 & $1(0.42 \%)$ & $3(1.26 \%)$ & $3(1.26 \%)$ & $1(0.42 \%)$ & $8(3.37 \%)$ \\
\hline High multiple +low & 0 & $1(0.42 \%)$ & $1(0.42 \%)$ & 0 & $2(0.84 \%)$ & $4(1.68 \%)$ \\
\hline Total & 0 & $2(0.84 \%)$ & $4(1.69 \%)$ & $3(1.26 \%)$ & $3(1.26 \%)$ & $12(5.06 \%)$ \\
\hline UI type (case, \%) & $1(0.42 \%)$ & $1(0.42 \%)$ & $2(0.84 \%)$ & $1(0.42 \%)$ & 0 & $5(2.10 \%)$ \\
\hline
\end{tabular}

Abbreviation: UI, unidentified.

Table 3. Incidence of HPV infection according to cytologic diagnosis

\begin{tabular}{|c|c|c|c|c|c|}
\hline \multirow{2}{*}{ HPV type (224 cases) } & \multicolumn{5}{|c|}{ Cytologic diagnosis } \\
\hline & normal & ASCUS & LSIL & HSIL & Invasive \\
\hline \multicolumn{6}{|l|}{ High-risk HPV (case, \%) } \\
\hline Single & 51 & 11 & 27 & 36 & 36 \\
\hline 2 types & 10 & 2 & 3 & 8 & 4 \\
\hline 3 types & 1 & 1 & 1 & 1 & 1 \\
\hline 4 types & 0 & 0 & 0 & 0 & 1 \\
\hline Total $(n=194)$ & $62(31.96 \%)$ & $14(7.22 \%)$ & $31(15.98 \%)$ & $45(23.20 \%)$ & $42(21.65 \%)$ \\
\hline \multicolumn{6}{|l|}{ Low-risk HPV (case, \%) } \\
\hline Single & 7 & 1 & 5 & 0 & 0 \\
\hline 2 types & 0 & 0 & 1 & 0 & 0 \\
\hline Total $(\mathrm{n}=14)$ & $7(50.0 \%)$ & $1(7.14 \%)$ & $6(42.86 \%)$ & 0 & 0 \\
\hline \multicolumn{6}{|l|}{ Mixed types (case, \%) } \\
\hline High single+low & 5 & 2 & 1 & 0 & 0 \\
\hline High multiple+low & 3 & 0 & 1 & 0 & 0 \\
\hline Total $(n=12)$ & $8(66.67 \%)$ & $2(16.67 \%)$ & $2(16.67 \%)$ & 0 & 0 \\
\hline UI tupes (case, \%) & 2 & 2 & 0 & 0 & 0 \\
\hline Total $(n=4)$ & $2(50 \%)$ & $2(50 \%)$ & 0 & 0 & 0 \\
\hline
\end{tabular}


the epidemiology of HPV infection among Mexican women with normal cervical cytology, reported a rate of HPV infection of $16.7 \%$ in the age group under 25 years, which declined to $3.7 \%$ in the age group 35-44 years, then increased progressively to $23 \%$ among women 65 years and older. Also, Stoler [16] described that age group 20 years in American women had the highest prevalence of HPV infection.

These discrepancies among several studies may be attributed to social or sexual cultural backgrounds.

Comparison of cytologic diagnosis with prevalence of HPV infection

Relationships between high- and low-risk HPV subtypes are described in Tables 3, 4, and 5. When comparing the cytologic diagnosis (224 women) by Pap smear and DNA chip positive (237 women) for HPV, 62 out of 194 women with high-risk HPVs (31.96\%), 7 of 14 women with low-risk HPVs $(50.0 \%), 8$ of 12 women infected with mixed types, and 2 of 4 women with unidentified HPV subtypes (50.0\%) had a normal cytology. In high-risk HPV-infected cases (194 of 224 women), 132 out of 194 women (68.04\%) suffered cervical lesions with ASCUS (14 patients, 7.22\%), LSIL (31 patients, $15.98 \%$ ), HSIL (45 patients, $23.20 \%$ ) and ICC (42 patients, 21.65\%). In low-risk HPV-infected cases (14 of 224 women), 7 women showed 1 case of ASCUS and 6 cases of LSIL, whereas 12 women infected with mixed subtypes (12/224 women) had 2 cases of ASCUS and 2 cases of LSIL, respectively. 2 of 4 women infected with unidentified HPV subtypes had ASCUS (Table 3).

In high-risk HPV, patients with ASCUS showed the highest prevalence of subtype 58 infection ( $5 / 23$ cases, $21.74 \%)$, whereas those with LSIL (11/50 cases, $22.00 \%)$, HSIL (31/55 cases, $56.36 \%)$, or ICC (26/51 cases, $50.98 \%)$ had more infections of subtype 16 than other subtypes, which were 58 , $53,18,52,33,31,35,54,56,39,45,51,59,66$, and 68, respectively (Table 4). On the other hand, low-risk HPV cases with LHIL showed the highest incidence of subtype 70 (10\%) (Table 5).

The results of the present study agree with previous studies, in the fact that high-risk HPV subtype 16 causes cervical cancer. An [1], Hong et al. [5], Hwang [6], Kahng and Lee

Table 4. Comparison and analysis between cytology diagnosis and high-risk HPV subtypes

\begin{tabular}{|c|c|c|c|c|c|c|}
\hline \multirow{2}{*}{ High-risk HPV } & \multicolumn{6}{|c|}{ Cytology diagnosis } \\
\hline & Normal(n=106) & ASCUS(n=23) & $\operatorname{LSIL}(n=50)$ & $\operatorname{HSIL}(n=55)$ & Invasive $(n=51)$ & Total $(n=285)$ \\
\hline Type 16 (no., \%) & 28 & 4 & 11 & 31 & 26 & 100 \\
\hline Type 58 (no., \%) & 12 & 5 & 4 & 4 & 5 & 30 \\
\hline Type 53 (no., \%) & 12 & 1 & 4 & 3 & 3 & 23 \\
\hline Type 18 (no., \%) & 8 & 2 & 3 & 3 & 7 & 23 \\
\hline Type 52 (no., \%) & 3 & 2 & 4 & 5 & 1 & 15 \\
\hline Type 33 (no., \%) & 3 & 2 & 1 & 2 & 2 & 10 \\
\hline Type 31 (no., \%) & 5 & 0 & 3 & 1 & 2 & 11 \\
\hline Type 35 (no., \%) & 3 & 0 & 1 & 1 & 3 & 8 \\
\hline Type 54 (no., \%) & 6 & 0 & 0 & 2 & 0 & 8 \\
\hline Type 56 (no., \%) & 2 & 1 & 2 & 0 & 1 & 6 \\
\hline Others (no., \%) & 9 & 4 & 7 & 3 & 1 & 24 \\
\hline Total (no., \%) & 91 & 21 & 40 & 55 & 51 & 258 \\
\hline
\end{tabular}

Abbreviation: Others, HPV subtypes 39, 45, 51, 59, 66 and 68.

Table 5. Comparison and analysis between cytology diagnosis and low-risk HPV subtypes

\begin{tabular}{lcccccc}
\hline \multirow{2}{*}{ Low-risk HPV type } & \multicolumn{5}{c}{ Cytology diagnosis } \\
\cline { 2 - 7 } & Normal(n=106) & ASCUS(n=23) & LSIL(n=50) & HSIL(n=55) & Invasive $(\mathrm{n}=51)$ & Total(n=285) \\
\hline Type 70 (no., \%) & 7 & 1 & 5 & 0 & 0 & 13 \\
Type 6 (no., \%) & 5 & 1 & 0 & 0 & 0 & 6 \\
Type 11 (no., \%) & 1 & 0 & 5 & 0 & 0 & 6 \\
Others (no., \%) & 2 & 0 & 0 & 0 & 0 & 2 \\
\hline Total (n=27) & 15 & 2 & 10 & 0 & 0 & 27 \\
\hline
\end{tabular}

Abbreviation: Others, HPV subtypes 40 and 44 . 
[7], Kim et al. [8] and Muñoz et al. [10] demonstrated a consistent finding that women with various cervical lesions including invasive squamous cancer had the highest prevalence of HPV subtype 16 infection. Rozendaal et al. [14] revealed that women with normal cervical smears containing high-risk HPV genotypes were 116 times more at risk of developing CIN (cervical intraepithelial neoplasia) III compared with women without high-risk HPV. Although the prevalence of HPV DNA associated with invasive cervical carcinoma differs among countries, the most common HPV types in invasive cervical cancer were, in order of decreasing prevalence, HPV 16, 18, 45, 31, 33, 58, 52, 35, 59, 56, 6, 51, $68,39,82,73,66$ and 70 . In squamous cell carcinoma, HPV subtype 16 was the predominant type (46-63\%) followed by HPV subtype 18 (10-14\%), 45 (2-8\%), 31 (2-7\%) and 33 (3-5\%) in all regions except Asia, where HPV subtypes $58(6 \%)$ and $52(4 \%)$ were more frequently detected. In adeno- and adenosquamous-carcinoma, the HPV prevalence was significantly lower $(76.4 \%)$ than in squamous cell carcinoma (87.3\%), and HPV subtype 18 was predominant in every region $(37-41 \%)$, followed by subtypes $16(26-36 \%)$ and 45 (5-7\%) [3]. Bosch et al. [2] found that $80-95 \%$ of patients suffering cervical cancer were infected with 5 subtypes such as HPV 16, 18, 31, 33, and 45. We support Bosch group's report by observing similar results.

In summary, the prevalence of HPV was $43.17 \%$. Women with high-risk HPV subtype, especially type 16 infection, may be exposed to higher risk of cervical lesions and thus regularly routine HPV test with DNA Chip for women will appear to be useful for protection and prognosis of cervical cancer.

\section{References}

1. An, H. J., N. H. Cho, S. Y. Lee, I. H. Kim, C. Lee, S. J. Kim, M. S. Mun, S. H. Kim and J. K. Jeong. 2003. Correlation of cervical carcinoma and precancerous lesions with human papillomavirus (HPV) genotypes detected with the HPV DNA chip microarray method. Cancer 97, 1672-1680.

2. Bosch, F. X., A. Lorincz, N. Muñoz, C. J. L. M. Meijier and K. V. Shak. 2002. The causal relation between human papillomavirus and cervical cancer. J. Clin. Pathol. 55, 244-265.

3. Clifford, G. M., J. S. Smith, M. Plummer, N. Muñoz and S. Franceschi. 2003. Human papillomavirus types in invasive cervical cancer worldwide: a meta-analysis. Br. J. Cancer 88, 63-73.

4. Cox, J. T., A. T. Lorincz, M. H. Schiffman, M. E. Sherman, A. Cullen and R. J. Kurman. 1995. Human papillomavirus testing by hybrid capture appears to be useful in triaging women with a cytologic diagnosis of atypical squamous cells of undetermined significance. Am. J. Obstet. Gynecol. 172, 946-954.

5. Hong, S. H., D. H. Lee and H. R. Shin. 2004. Prevalence of human papillomavirus infection in women in South Korea. The Korean Journal of Cytopathology 15, 17-27.

6. Hwang, T. S. 1999. Detection and typing of human papillomavirus DNA by PCR using consensus primers in various cervical lesions of Korea women. J. Korean Med. Sci. 14, 593-599.

7. Kahang, J. M. and H. J. Lee. 2008. Clinical efficacy of HPV DNA chip test in the era of HPV vaccination: 1,211 cases, a single institution study. Korean J. Lab. Med. 28, 70-78.

8. Kim, S. R., S. Y. Song, D .S. Kim, J. W. Lee, C. S. Park, D. S. Bae, H. J. Lee, K. T. Kim, O. J. Kwon, E. S. Song, H. J. Joo and G. W. Ahn. 2004. Evaluation of self-collected pad sampling for the detection of HPV in cervicovaginal secretion. The Korean Journal of Pathology 38, 258-264.

9. Kinney, W. K., M. M. Manos, L. B. Hurley and J. E. Ransely. 1998. Where's the high-grade cervical neoplesia? the importance of minimally abnormal Papanicolaou diagnoses. Obstet. Gynecol. 91, 973-976.

10. Lazacano-Ponce, E., R. Herrero and N. Muñoz. 2001. Epidemiology of HPV infection among Mexican women with normal cervical cytology. Int. J. Cancer 91, 412-420.

11. Muñoz, N., X. Bosch, S. de Snajosé, R. Herrero, X. Castellsagué, K. V. Shah, P. J. F. Sanijders and C. J. L. M. Meijer. 2003. Epidemiologic classification of human papillomavirus types associated with cervical cancer. N. Engl. J. Med. 348, 518-527.

12. National Institutes of Health Consensus Development Conference statement on cervical cancer, 1997. Gynecol. Oncol. 66, 351-361.

13. Recommendations for cervical screening 1997. Members of the Working Party on Cervical Screening. 1998. N. Z. Med. J. 111, 94-98.

14. Rozendaal, L., J. M. Walboomers, J. C. van der Linden, F. J. Voorhorst, P. Kenemans, T. J. Helmerhorst, M. van Ballegooijen and C. J. Meijer. 1996. PCR-based high-risk HPV test in cervical cancer screening gives objective risk assessment of women with cytomorphologically normal cervical smears. Int. J. Cancer 68, 766-769.

15. Sherman, M. E., M. H. Schiffman and A. T. Lorincz. 1994. Toward objective quality assurance in cervical cytopathology: correlation of cytopathologic diagnoses with detection of high-risk human papillomavirus types. Am. J. Clin. Pathol. 102, 182-187.

16. Stoler, M. H. 2000. Advances in Cervical Screening Technology. Mod. Pathol. 3, 275-284.

17. Wright, T. C., X. W. Sun and J. Koulos. 1995. Comparison of management algorithms for the evaluation of women with low-grade cytologic abnormalities. Obstet. Gynecol. 85, 202-210.

18. Zur Hausen, H. 1988. Papillomavirus in human cancers. Mol. Carcinog. 1, 147-150. 


\section{초록 : 여성에 있어 DNA 칩검사에 의한 인유두종바이러스 감염률의 조사}

김재우 $\cdot$ 김윤태 ${ }^{1} \cdot$ 김대식 ${ }^{2} \cdot$ 최석철*

(부산가톨릭대학교 보건과학대학 임상병리학과, ${ }^{1}$ 서울의과학연구소, ${ }^{2}$ 동남보건대학 임상병리과)

우리는 549명의 여성을 대상으로 HPV DNA Chip을 이용하여 자궁경부암의 주요 원인인 HPV 감염률을 조사하 고 Pap 도말 염색법을 이용한 세포학적 검사를 실시하였다. 전체 대상여성 549명 중 237명 HPV DNA Chip 검사에 서 양성 이었다(43.17\%). 237명 중 203명이 고위험군 $\mathrm{HPV}$ 아형에 감염되었고(88.61\%, 고위험군), 17 명이 저위험군 $\mathrm{HPV}$ 아형에 감염되었고(7.17\%, 저위험군), 나머지 17 명은 고위험군 아형, 저위험군 아형, 미확인 아형에 감염 되었 다(7.17\%, 혼합형). 연령별 감염률은 20 대가 $1.26 \%, 30$ 대 $15.61 \%, 40$ 대 $31.65 \%, 50$ 대 $23.21 \%, 60$ 대 이상이 $13.92 \%$ 으로 확인되었다. 저위험군과 혼합군에서 고위험군보다 HPV 감염의 빈도가 더 낮게 나타났다. 세포학적 진단결과(224명 의 여성)와 HPV chip 양성(237명의 여성)여성 간의 비교에서 고위험군의 경우 194 명중 132 명(68.04\%)이 ASCUS (atypical squamous cells of undetermined significance, 7.22\%), LSIL (low grade squamous intraepithelial lesion, $15.98 \%$ ), HSIL (high grade SIL, $23.20 \%$ ), 자궁경부암(21.65\%) 등과 같은 자궁경부질환이 있었다. 저위험군(224 여성 중 14명)의 경우 ASCUS 1예와 LSIL 6예였는데 비해 혼합군(224 여성 중 4명)의 경우에는 단지 2예의 ASCUS 만이 있었다. 고위험 HPV 아형16 및 18에 감염된 여성은 각각 26예 및 7예의 자궁경부암이 있었으나 저위험군 $\mathrm{HPV}$ 아형 및 기타 아형의 경우 자궁경부암 발생이 매우 낮거나 없었다. 결론적으로 본 연구에서 $43.17 \%$ 의 HPV 유병률을 보였고 고위험 $\mathrm{HPV}$ 아형16이 감염된 여성들에 있어 전암 병변 또는 자궁경부암의 원인이 되는 주요 인자이며 HPV DNA chip 검사는 HPV 감염 유무를 진단하는 정밀하고 유용한 방법임을 시사하고 있다. 